\title{
Habitat Selection and Vegetational Charac- teristics of Antelope Fawn Bedsites in West
}

Texas

RONALD D. TUCKER AND GERALD W. GARNER

Abstract

Vegetative composition, dominance, and height of cover characteristics were measured at 60 daytime bed sites of pronghorn antelope (Antilocapra americana) fawns in a desert grassland in southwest Texas. Fawns were fitted with radio transmitters and were located daily between 8 May and 9 July 1978. Igneous hill and mountain range sites were used $69 \%$ of the time during the first 4 weeks of age. Black grama (Bouteloua eriopoda), sideoats grama (B. curtipendula), hairy grama (B. hirsuta), and cane bluestem (Bothriochloa barbinodes) were the dominant species at bedsites of fawns 1 to 4 weeks of age. Cane bluestem and sideoats grama were the tallest species, averaging 52 and $\mathbf{4 2} \mathrm{cm}$ in height, respectively. Blue grama (B. gracilis), tobosa grass (Hilaria mutica), and black grama were the species that occurred most often at bedsites of fawns 4 to 8 weeks of age. Cane bluestem, threeawns (Aristida spp.), sideoats grama, and tobosa grass had average heights of $\mathbf{4 6}$ $\mathrm{cm}, 38 \mathrm{~cm}, 41 \mathrm{~cm}$, and $43 \mathrm{~cm}$, respectively. Cover characteristics of the bedsites were taller than cover characteristics of the surrounding area $(P<0.015)$ for fawns less than 4 weeks of age, but were the same for fawns over 4 weeks of age. Shrubs were not a major component of any bedsite. Management of areas used by fawns less than 4 weeks of age may be critical to young survival.

Pronghorn antelope fawns are known to lie in seclusion up to $90 \%$ of the daytime hours during the first few weeks of life (Buechner 1950, Fichter 1974, Kitchen 1974). Autenrieth and Fichter (1975) discussed the behavior of the fawn when selecting daytime bedsites. The fawn's apparent examination of the vegetation or ground surface was noted, and on several occasions a fawn would lie down in several different areas before a bedsite was finally chosen. Fawn bedsites in Montana (Pyrah 1974) and Idaho (Authenrieth 1976) were reported as being dominated by big sagebrush (Artemisia tridentata). Sagebrush heights in these areas ranged from 25 to $50 \mathrm{~cm}$. Bedsite information has not been reported for habitats, such as desert grassland areas, in which sagebrush is not a major habitat component. A study of pronghorn antelope-fawn mortality in the Trans-Pecos region of Texas provided an opportunity to locate and measure fawn bedsites (Tucker and Garner 1980) in such a habitat.

\section{Study Area}

The study area, located northeast of Alpine in Brewster County, Texas (Fig. 1), is a 6,100-ha pasture with topography ranging from nearly level rangelands to gently rolling hills (Fig. 2). The area is a

During the research, the authors were, respectively, graduate student and assistant professor, Range Animal Science Department, Sul Ross State University. Alpine, Texas 79830. Tucker is currently wildlife biologist, Bureau of Land Management, Cedar City, Utah 84720 . Garner is presently wildlife biologst, Arctic National Wildlife Refuge, U.S. Fish and Wildlife Service, Fairbanks, Alaska 99701.

The authors gratefully acknowledge the field assistance of C. Freeman, M. Howard, T. Payton, D. Ratliff, M. Redus, and G. Wampler. Dr. James C. Lewis, Dr. Jeff Powell, and Dr. John A. Morrison provided helpful suggestions on the manuscript. Financial support was provided by the Houst on Livestock Show and Rodeo, Houston. Texas, and the Department of Range Animal Science, Sul Ross State University, Alpine, Texas.

Manuscript received December 4, 1980

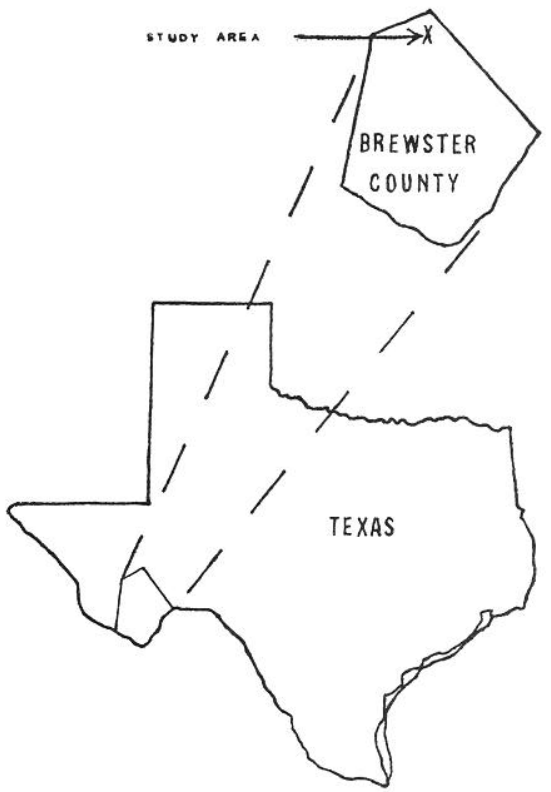

Fig. 1. Location of pronghorn fawn study area in Brewster County, Texas.

desert grassland and receives 30 to $36 \mathrm{~cm}$ average annual rainfall, the majority of which occurs between July and September (Martin 1975). Range sites present in the study area are the igneous hill and mountain, gravelly, loamy, and draw range sites (Fig. 3).

Igneous hill and mountain range sites occupy approximately $15 \%$ of the study area and occur on rolling to steep hills and mountains with slopes varying from 8 to $30 \%$. Soils are shallow, stoney loams intermixed with coarse igneous gravel and rocks

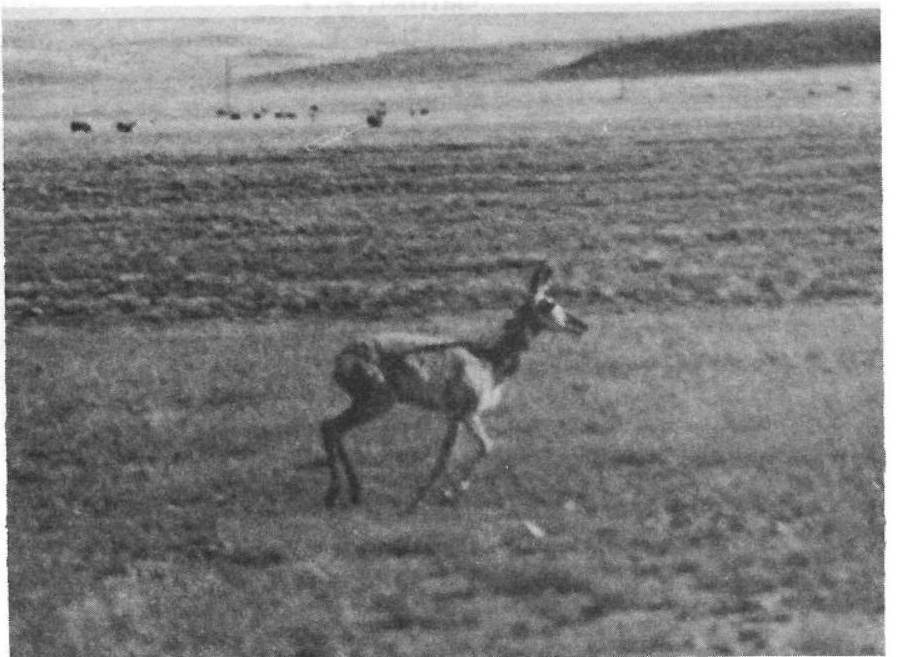

Fig. 2. Pronghorn fawn study area near Alpine in Brewster County, Texas. 
containing frequent boulders and outcrops. Climax vegetation is a mixture of both short and mid-grasses with sideoats grama, cane bluestem, blue grama, and black grama as the major grass speces (Soil Conservation Service 1978, unpublished data).

Gravelly range sites make up approximately $75 \%$ of the study area. Topography is level to gently rolling hills. Soils are shallow to moderately deep gravelly loams. Vegetation is dominated by short and mid-grasses, with mid-grasses being found in areas with higher moisture regimes. Major grass species are sideoats grama, cane bluestem, and green sprangletop (Leptochloa dubia). If overgrazing occurs, these species decrease and shorter grasses, such as tobosa grass, blue grama, and black grama increase (Soil Conservation Service 1978, unpublished data).

Loamy range sites, with deep, fine textured loam soils, occur on approximately $5 \%$ of the study area. Grass species are primarily short and mid-grasses with sideoats grama, cane bluestem, green sprangletop, and vine mesquite (Panicum obtusum) dominating sites in excellent condition. Blue grama, black grama, and tobosa grass increase if overgrazing occurs (Soil Conservation Service 1978, unpublished data).

Draw range sites consist of narrow, frequently flooded a reas on approximately $5 \%$ of the study area. Soils are deep loams with high water-holding capacities. These sites are dominated by short to mid-grasses with an intermittent overstory of shrubs and trees. Grasses include sideoats grama, cane bluestem, alkali sacaton (Sporobolus airoides), vine mesquite, and green sprangletop. Trees and shrubs include spanish walnut (Juglans microcarpa), cottonwood (Populus sargentii), Apache-plume (Fallugia paradoxa), and mesquite (Prosopis juliflora). Forbs are also prominent on these sites (Soil Conservation Service 1978, unpublished data).

\section{Materials and Methods}

Fawns were captured using a nighttime capture technique (Browlee and Hailey 1970) and fitted with radio transmitters. Age of captured fawns was determined by techniques described by Tucker and Garner (1980). Daytime bed sites were located by triangulation and subsequent observation of the bedded fawns. From May through July 1978, 186 daytime bedsites were located. These locations were made between 0800 and $1100 \mathrm{hr}$, recorded on topographical maps, and the range site was recorded. Chi-square tests (Steel and Torrie 1960) were used to test preferences for daytime bedsites located on different range sites by fawns less than 30 days of age and by fawns greater than 30 days of age.

Thirty bedsites of fawns less than 30 days of age and 30 bedsites of fawns greater than $\mathbf{3 0}$ days of age were located at random during May, June, and July, 1978. Bedsites of fawns less than 30 days of age were termed "fawning area" bedsites, and bedsites of fawns greater than 30 days of age were termed "fawn rearing area" bedsites.

Each bedsite was divided into 2 areas. The exact location of the bedded fawn was considered the bedsite. The area immediately surrounding the bedsite was considered the bedsite area. In order to avoid disturbing fawning areas, bedsite sampling was cond ucted after most fawns had reached 30 days of age. Less than $1 \mathrm{~cm}$ of precipitation fell between bedsite location and subsequent sampling. Significant changes in vegetation were not apparent during this 6 week period.

Bedsites were sampled using the bedsite as the center of 4 radii, each radius being placed along the slope and perpendicular to the slope. Ten $20 \times 50-\mathrm{cm}$ frames (Daubenmire 1959) were sampled at $20-\mathrm{cm}$ intervals along each radius. Within each frame, the vertical heights of the tallest plant species (grass, forb, shrub) and/or rock were measured to the nearest $5 \mathrm{~cm}$. The 4 most dominant plant species within each frame were ranked in order of dominance. Dominance of individual plant species was determined by ocularly estimating the amount of biomass present, basal diameter, and vertical height. In all instances the dominance of a plant was based on those plants found in each individual frame. This information was compiled to identify the dominance and frequency of plant species surrounding the besite.
The first 2 frames in each radius (frames nearest the bed site) were examined and compared statistically to the remaining 8 frames in each radius, using the averaged heights of the 4 cover measurements (grass, forb, shrub, and rock). The mean height of cover characteristics at the bedsite were compared to the mean height of the cover characteristics found immediately surrounding the bedsite. A $t$-test was used to test whether or not fawns were selecting daytime bedsites with taller plant cover (Steel and Torrie 1960).

\section{Result and Discussion}

\section{Range Sites of Daytime Bedsites}

Igneous hill and mountain range sites were selected significantly more often $(P<0.05)$ as daytime bedsites by fawns less than 4 weeks old (Table 1). Of the 132 daytime bedsites of fawns less than 30 days of age, $69 \%$ were found on igneous hill and mountain range sites. Fawns less than $\mathbf{3 0}$ days old also utilized the gravelly, draw, and loamy range sites as daytime bedsites (Table 1), but at rates less than expected by their representation of total area.

When fawns were 4 to 6 weeks old, they gradually moved to the lower hills and flats where they formed fawn/doe social groups (Autenrieth and Fichter 1975). The gravelly range sites were selected in 43 of 54 daytime bedsite locations (80\%). At this age, fawns did not utilize the igneous hill and mountain range sites any more than would occur with normal distribution of bedsites $(P<0.10)$. The draw and loamy range sites were not utilized as daytime bedsites by fawns over 4 weeks old (Table 1).

Beale and Smith (1973) found that areas near washes or draws were frequently used by predators and a number of predatorinvolved mortalities occurred when fawns were bedded nearby. Predation by coyotes and bobcats may have attributed to the draw and loamy range sites not being utilized as bedsites.

Table 1. Range sites and their use as antelope fawn daytime bedsites in Brewster County, Texas, 1978.

\begin{tabular}{|c|c|c|c|}
\hline \multirow[b]{2}{*}{ Range site } & \multicolumn{3}{|c|}{$\%$ of bedsite locations } \\
\hline & $\begin{array}{c}\% \text { of } \\
\text { study area }\end{array}$ & $\begin{array}{c}\text { Fawns }<30 \\
\text { days old }\end{array}$ & $\begin{array}{c}\text { Fawns }>30 \\
\text { days old }\end{array}$ \\
\hline \multicolumn{3}{|l|}{ Igneous Hill } & 20 \\
\hline Gravelly & 75 & $27^{2}$ & 80 \\
\hline Loam & 5 & 3 & 0 \\
\hline Draw & 5 & 1 & 0 \\
\hline
\end{tabular}

'Chi-squared test $(P<0.05)$ indicates use above expected if use were proportional to availability.

${ }^{2}$ Chi-squred test $(R<0.05)$ indicates use below expected is use were proportional to availability.

\section{Daytime Bedsites in Fawning Areas}

Black grama, sideoats grama, hairy grama, and cane bluestem were the most frequent species surrounding the 30 daytime bedsites analyzed in fawning areas (Table 2). Cane bluestem was the tallest species, averaging $52 \mathrm{~cm}$ in height. Sideoats grama, black grama, and hairy grama averaged $42 \mathrm{~cm}, 18 \mathrm{~cm}$, and $17 \mathrm{~cm}$ in height, respectively. Black grama was considered the dominant species at daytime bedsites, with sideoats grama second in dominance.

Mesquite, sacahuista (Nolina microcarpa), javalina bush (Condalia ericoides), and catclaw (Mimosa biuncifera) were shrub species that occurred at these bedsites, and had a combined frequency of $1 \%$. The mean height of these shrub species was $51 \mathrm{~cm}$. Shrubs were not a major vegetation component a round daytime bedsites.

Rocks occurred around all daytime bedsites in fawning areas. Heights ranged from 0 to $45 \mathrm{~cm}$, with the average height being 5 $\mathrm{cm}$. Slope averaged $6 \%$ and ranged from 0 to $14 \%$.

\section{Daytime Bedsites in Fawn Rearing Areas}

Blue grama, tobosa grass, black grama, and muhly (Muhlenbergia spp.) composed $53 \%$ of the species recorded around daytime bedsites in fawn rearing areas (Table 3). Cane bluestem was the tallest plant, with a mean height of $46 \mathrm{~cm}$. Threeawn, sideoats 
Table 2. Dominance rankings and frequency of grass species around daytime bedsites of pronghorn antelope fawns in fawning areas, Brewster County, Texas, 1978.

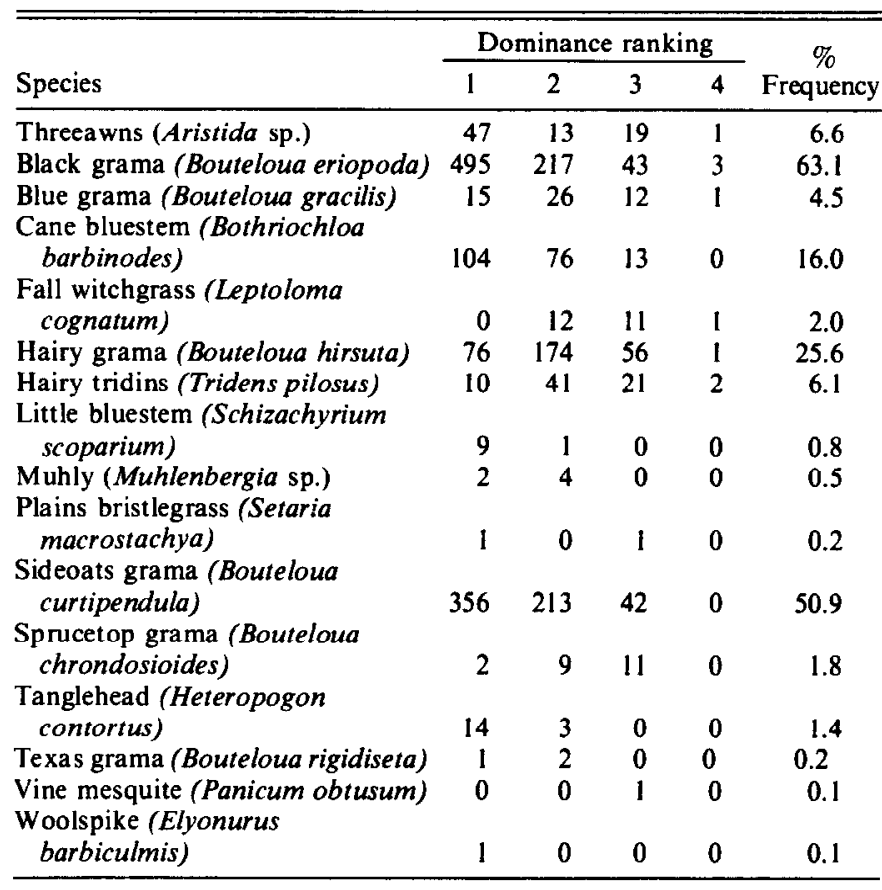

grama, and tobosa grass averaged $38 \mathrm{~cm}, 41 \mathrm{~cm}$, and $43 \mathrm{~cm}$ in height, respectively. Blue grama was the dominant plant around daytime bedsites and tobosa grass was second in dominance.

Javalina bush and yucca (Yucca torreyi) were the only shrub spccics occurring around daytime bedsites in fawn rearing areas. These species were relatively infrequent (less than $1 \%$ ). Mean height of these species averaged $26 \mathrm{~cm}$. Shrubs did not appear to be an important vegetative component at daytime bedsites.

Rocks occurred at or near all daytime bedsites in fawn rearing areas. Rock heights ranged from 0 to $30 \mathrm{~cm}$, with the average height being $5 \mathrm{~cm}$. Slope ranged from 0 to $13 \%$ averaging $2 \%$.

Table 3. Dominance rankins and frequency of grass species around daytime bedsites of pronghorn antelope fawns in fawn rearing areas, Brewster County, Texas, 1978.

\begin{tabular}{|c|c|c|c|c|c|}
\hline \multirow[b]{2}{*}{ Species } & \multicolumn{4}{|c|}{ Dominance ranking } & \multirow{2}{*}{$\begin{array}{c}\% \\
\text { Frequency }\end{array}$} \\
\hline & 1 & 2 & 3 & 4 & \\
\hline Threeawns (Aristida sp.) & 52 & 38 & 22 & 0 & 9.33 \\
\hline Black grama (Bouteloua eriopoda) & 231 & 70 & 9 & 0 & 25.83 \\
\hline Blue grama (Bouteloua gracilis) & 363 & 197 & 21 & 1 & 48.50 \\
\hline Buffalo grass (Buchelo dactyloides) & 3 & 5 & 1 & 0 & 0.75 \\
\hline $\begin{array}{l}\text { Burro grass (Scleropogon brevi- } \\
\text { folius) }\end{array}$ & 19 & 18 & 5 & 0 & 3.50 \\
\hline Cane bluestem (Bothriochloa & & & & & \\
\hline barbinodes) & 14 & 13 & 8 & 1 & 3.00 \\
\hline Chloris (Chloris virgata) & 25 & 35 & 5 & $i$ & 5.50 \\
\hline Fall witchgrass (Leptoloma & & & & & \\
\hline cognatum) & 4 & 6 & 7 & 1 & 1.50 \\
\hline Hairy grama (Bouteloua hirsuta) & 49 & 56 & 12 & 0 & 9.75 \\
\hline Hairy tridins (Tridens pilosus) & 6 & 40 & 23 & 0 & 5.75 \\
\hline Muhly (Muhlenbergia sp.) & 66 & 65 & 12 & 2 & 12.08 \\
\hline $\begin{array}{l}\text { Sideoats grama (Bouteloua curti- } \\
\text { pendula) }\end{array}$ & 46 & 41 & 7 & 1 & 7.92 \\
\hline $\begin{array}{l}\text { Sprucetop grama (Bouteloua } \\
\text { chrondosioides) }\end{array}$ & 1 & 1 & 1 & I & 0.25 \\
\hline $\begin{array}{l}\text { Tobosa grass (Hilaria mutica) } \\
\text { Tumblegrass (Schedonnardus }\end{array}$ & 272 & 39 & 6 & 0 & 26.41 \\
\hline paniculatus) & 1 & 5 & 0 & 0 & .50 \\
\hline Vine mesquite (Panicum obtusum) & 17 & 14 & 10 & 0 & 3.42 \\
\hline $\begin{array}{l}\text { Woolspike (Elyonurus } \\
\text { barbiculmis) }\end{array}$ & 0 & 0 & 1 & 0 & 0.08 \\
\hline
\end{tabular}

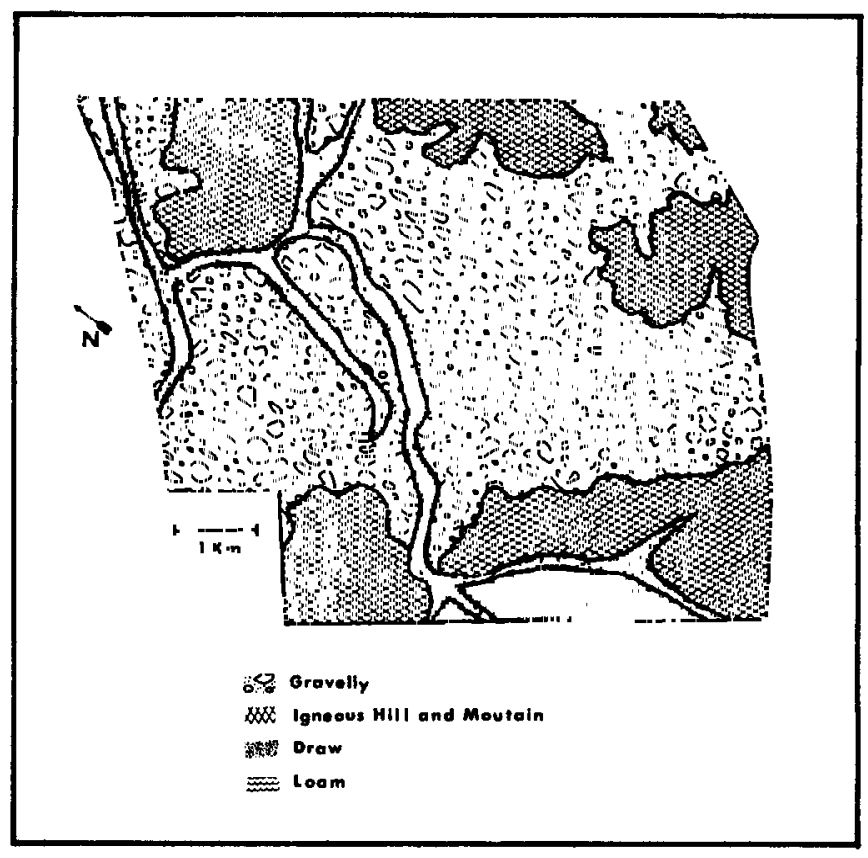

Fig. 3. Range sites on a pronghorn antelope research area near Alpine in Brewster County, Texas, 1978.

\section{Daytime Bedsites Versus Daytime Bedsite Areas}

Fawns less than 4 weeks old selected bedsites that had significantly taller cover characteristics at the bedsite than in the surrounding area $(19 \pm 0.67 \mathrm{~cm}$ averaged height at the bedsite vs. $17 \pm$ $0.27 \mathrm{~cm}$ averaged height away from the bedsite, $t=3.877,29 \mathrm{df}$, $P<0.05$ ). Plants at the bedsites were taller than plants that surrounded the bedsites. Heights of cover characteristics at and surrounding daytime bedsites in fawn rearing areas (fawns 4 to 8 weeks of age) were compared; however, no statistical differences were detected $(13 \pm 1.03 \mathrm{~cm}$ at the bedsite vs. $15 \pm 1.12 \mathrm{~cm}$ surrounding the bedsite, $t=0.563,29 \mathrm{df}, P>0.05)$. These data indicate that antelope fawns in the Trans-Pecos tend to select daytime bedsites with taller cover characteristics until they reach 4 weeks of age, but did not show this preference from 4 to 8 weeks of age.

Autenrieth and Fichter (1975) found that fawns were selective in choosing areas with greater brush canopy cover, total coverage, and brush height. Brush, however, was not an important component at fawn bedsites in Texas. In Idaho, an average vegetation height of $41.9 \mathrm{~cm}$ has been reported at fawn bedsites (Authenrieth 1976). These data are comparable to mean vegetation heights of $42.6 \mathrm{~cm}$ in the fawning areas in the Trans-Pecos study area.

The height of vegetation or a combination of the various cover characteristics of the area are an important factor in the fawn's selection of a bedsite. In some areas of the Trans-Pecos where antelope populations are low, proper management of fawning areas could be beneficial to fawn survival. Barrett (1981) found that habitat diversity provided by sagebrush (Artemisia sp.), small depressions, and stands of grasses or forbs greater than $25 \mathrm{~cm}$ tall constituted important bedding cover and contributed to fawn survival. During this study, predation concentration on young fawns was determined to be a major limiting factor (Tucker and Garner 1980), with $60 \%$ of the fawns being lost due to predation during the first 6 weeks of life. Cane bluestem and sideoats grama are species which occur most often at and near young fawn's daytime bedsites. Although these species provide concealment for the fawn, they are also highly desirable livestock forages. Reduction of these species by grazing may affect fawning survival by reducing concealment cover for the fawns. 


\section{Literature Cited}

Autenrieth, R.E. 1976. A study of birth sites selected by pronghorn does and the bedsites of fawns. Proc. Antelope States Workshop 7:127-132.

Autenrieth, R.E., and E. Fichter. 1975. On the behavior and socialization of pronghorn fawns. Wildl. Monogr. 42:1-111.

Barrett, M.W. 1981. Environmental characteristics and functional significance of pronghorn fawn bedding sites in Alberta. J. Wildl. Manage. 45:120-131.

Beale, D.M., and A.D. Smith. 1973. Mortality of pronghom antelope fawns in western Utah. J. Wildl. Manage. 37:343-352.

Brownlee, S., and T.L. Hailey. 1970. Development of a technique for night trapping antelope fawns. Proc. Antelope States Workshop. 4:78-81.

Buechner, J. 1950. Life history, ecology, and range use of pronghorn antelope in Trans Pecos, Texas. Amer. Midl. Natur. 43:257-354.

Daubenmire, R.F. 1959. A canopy coverage method of vegetation analysis. Northwest Sci. 33:43-64.
Fichter, E. 1974. On the bedding behavior of pronghorn fawns. Pages 352-355. In: V. Geist and F. Walther, ed. The behavior of ungulates and its relation to management. IUCN Publ. New Series No. 24, 2 Vol.

Kitchen, D.W. 1974. Social behavior and ecology of the pronghorn. Wild. Monogr. 38:1-96.

Martin, C.S. 1975. Ecology and management of southwestern semidesert grass-shrub ranges, status of our knowledge. USDA-FS Res. Pap. R.M. 156.

Pyrah, D. 1974. Antelope fawn bedding cover selection in central Montana. Proc. Antelope States Workshop. 6:113-121.

Steel, R.G.D., and J.H. Torrie. 1960. Principles and procedures of statistics. McGraw Hill Book Co., Inc., New York.

Tucker, R.D., and G.W. Garner. 1980. Mortality of pronghorn antelope fawns in Brewster County, Texas. Proc. Annu. Conf. West. Assoc. Fish Wild. Agencies. 60:620-631.

Tucker, R.D., and G.W. Garner. 1980. Age determination in pronghorn antelope fawns. Proc. Antelope States Workshop. 9:271-278.

\section{POSITION ANNOUNCEMENT}

\section{Position:}

Extension Range Management Specialist in Morocco. Two year contract on a year by year basis.

Desired Qualifications:

Ph.D. in Range Science with international experience. Interest and experience in extension demonstration, application of range management practices, and applied research.

Desired Language Capability:

English, French and Arabic

Location:

Range extension work in the Ait Rbaa area near Beni Mellal, Morocco. Living accommodations in Beni Mellal, a small comfortable Moroccan town at the foothills of the High Atlas Mountains. Beni Mellal is a traditional Moroccan town located 250 kilometers inland from the capitol city of Rabat. An American School for pre-school through high school is located in Rabat.

\section{Responsibilities:}

The project centers around extension demonstration programs. All project activities focus on these demonstrations and use of them to encourage the acceptance of range management in Morocco. To the end, daily activities will be devoted toward developing and dlivering training programs designed for various local audiences. In collaboration with Moroccan counterparts, this person will compile basic resource/user inventories, evaluate range management techniques and practices, establish demonstrations of range management techniques and practices, and develop range management extension programs for range extension locations.

Salary and Benefits:

Salary negotiable and commensurate with responsibilities, qualifications and experience. Benefits totaling approximately $27 \%$ of salary, provided by Utah State University, include TIAA/CREF retirement at $14.2 \%$ of salary, a comprehensive life and medical insurance program that is honored worldwide, workers compensation, tuition reduction for college age children attending Utah State University, twenty two days of annual leave per year, and twelve days per year sick leave.

Closing Date:

April 1, 1983, or until a suitable candidate is identified.

Application:

Letter of application, a resume of professional experience, and letters of reference from at least five individuals familiar with the candidate's professional competence should be sent to James $T$. O'Rourke, Range Science Depatment, UMC 52, Utah State University, Logan, Utah, 84322. Utah State University is an EEO/AA employer. 